\title{
Teknokultura
}

ISSNe: 1549-2230

http://dx.doi.org/10.5209/TEKN.59362

\section{Time's Up, celebrities and the transformation of gender violence paradigms: The case of Oprah Winfrey's Speech at the Golden Globes (2018) ${ }^{1}$}

\author{
Rebeca Maseda García²; Emma Gómez Nicolau ${ }^{3}$
}

Recibido: 1 de abril de 2018 / Revisado: 14 de junio de 2018 / Aceptado: 21 de agosto de 2018. Open peer reviews

\begin{abstract}
In this paper we assess to what extent Oprah Winfrey's speech during the Golden Globes 2018, situated in the new context of the \#MeToo movement and the Time's Up initiative, destabilizes the modes of recognition of gender violence, offering an example of the operationalization of the concept of 'ethical witnessing' in communication media brought about by celebrities. In order to do so we consider the connections she establishes between the fight for rights and other fights for recognition, redistribution and participation; the degree of transgression of the reified models of identification of the subjectvictim and the focus on the capacity of agency; and the type of relationship that develops between the subject who gives testimony and the witness. The paper concludes that Oprah's intersectional approach to gender violence, her focus on agency and resistance (verging on heroism), her role as both witness of her own victimization and facilitator of others' testimonies, and her activism and inspiration for others to engage socially and politically, comes close to transgressing the boundaries of the current mode of recognition and representation of gender violence. Nevertheless, the widely accepted image of Oprah as an authority assumes a hierarchical relation that contravenes an ethical dimension of witnessing. In addition, in line with a liberal position, Oprah reimagines the 'good victim' as an empowered individual who overcomes vulnerability, and she envisions the eradication of gender inequality as something that comes from the top down.
\end{abstract}

Keywords: activism; confession; ethical witnessing; intersectionality; victim.

\section{[es] Time's Up, celebridades y la transformación del paradigma de la violencia de género: el caso del discurso de Oprah Winfrey en los Globos de Oro (2018)}

Resumen. En este trabajo evaluamos hasta qué punto el discurso de Oprah Winfrey durante los Golden Globes 2018, ubicado en el nuevo contexto del movimiento \#MeToo y la iniciativa Time's $U p$, desestabiliza los modos de reconocimiento de la violencia de género, ofreciendo un ejemplo de operacionalización del concepto de 'testimonio ético' aplicado a la acción de celebridades en los medios de comunicación. Para hacerlo, consideramos las conexiones que se establecen entre la lucha por los derechos de las mujeres y otras luchas por el reconocimiento, la redistribución y la participación; el

1 This article is part of the project La re-significación de la mujer-víctima en la cultura popular: Implicaciones para la innovación representacional en la construcción de la vulnerabilidad y la resistencia [The re-signification of woman as victim in popular culture: implications towards representational innovation in the construction of vulnerability and resistance] (FEM2015-65834-C2-2-P, MINECO-FEDER), funded by Spain's Ministery of Economy and Competitivity. We would like to express our gratitude to Drs. Zeynep Kiliç, Dr. Dayna DeFeo and Patrick Dulin for their invaluable feedback and support, and to Dr. María José Gámez Fuentes for her constant inspiration. We also appreciate the blind reviewers for their thoughtful comments.

2 University of Alaska Anchorage (USA) email: rebeca.maseda@alaska.edu

3 Universitat Jaume I (Spain) email: enicolau@uji.es 
grado de transgresión de los modelos reificados de identificación del sujeto-víctima y el enfoque en la capacidad de agencia; y el tipo de relación que se desarrolla entre el sujeto que da el testimonio y el testigo. El documento concluye que el enfoque interseccional de Oprah respecto a la violencia de género, su enfoque en agencia y resistencia (rayando en heroísmo), su papel como testigo de su propia victimización y facilitador de los testimonios de los demás, y su activismo e inspiración para que otros participen social y políticamente, están cerca de transgredir los límites del modo actual de reconocimiento y representación de la violencia de género. Sin embargo, la imagen ampliamente aceptada de Oprah como autoridad toma una relación jerárquica que contraviene una dimensión ética del testimonio. Además, Oprah vuelve a imaginar a la "buena víctima" como una persona empoderada que supera la vulnerabilidad, al mismo tiempo que concibe la erradicación de la desigualdad de género como algo que se genera de arriba hacia abajo.

Palabras clave: activismo; confesión; interseccionalidad; testimonio ético; víctima.

Summary. 1. Introduction. 2. Ethical witnessing for transformation. 3. Intersectionality, representation, and the interweaving of violence with oppression. 4. Vulnerability, agency, resistance and the subjectvictim. 5 . Testimony and bearing witness. 6 . Women march on: Conclusions.

Cómo citar: Maseda García, R. \& Gómez Nicolau, E. (2018). Time’s Up, celebrities and the transformation of gender violence paradigms: The case of Oprah Winfrey's Speech at the Golden Globes, en Teknokultura, 15(2), 193-205.

\section{Introduction}

On January 7 2018, the African-American media tycoon, philanthropist, activist, and influencer Oprah Winfrey delivered an acceptance speech at the Golden Globes ceremony. She spoke in front of an audience full of celebrities wearing black as symbol of protest against sexual harassment and violence suffered by women, in a context where revelations in mass have stirred a tide of indignation and a call to action worldwide. In the audience, as she was speaking, nods, smiles, tears, and a standing ovation communicated the energy and momentum of the \#MeToo, Time's $U p$ and other similar movements around the world.

Celebrities have been increasingly involved in denouncing gender violence, capitalizing on their social influence to raise consciousness and mobilize a vast number of people. This raises questions regarding to what extent their actions really contribute to the transformation of the current framework of recognition of gender-based violence. In their study, Gámez Fuentes, Gómez Nicolau and Maseda García (2016) analyzed Beyoncé's musical performances using feminist imaginary, an interview with Spanish actress Carmen Maura revealing a rape event, and Emma Watson's \#HeForShe media campaign. The objective was to identify the celebrities' degree of transgression of the reified representational models of the subject-victim, the potential to reconfigure the relationship between the subject-victim and the witness, and the connections with women's fights for their rights and other social movements. The authors concluded that although celebrities can destabilize hegemonic narratives about violence, their actions do not necessarily constitute a re-signification of the framework of recognition. First, they can be co-opted by the 'celebrity economy' (whose role in the entertainment industry mainly depends on the market laws) and/or be absorbed by liberal feminism (successful women who find a balance between feminist vindications 
and the fight against gender-based violence with consumerism, materialism and capitalism). Furthermore, their social status complicates the comprehension of women's shared nature of vulnerability, and could be criticized on the basis of disassociation from a collective fight.

In this article we aim to elucidate if Oprah's speech, situated in the new context of the \#MeToo movement and the Time's Up initiative, offers an example of 'ethical witnessing' regarding gender violence in celebrity culture. \#MeToo, the hashtag used in the social media campaign initiated in October 2017 to denounce sexual abuse and sexual harassment in the film and entertainment industry, became viral, and it prompted the Time's Up initiative. Signed by more than 300 actresses $^{4}$, Time's Up constitutes a major action to denounce the pervasiveness of sexual abuse and coercion, and ultimately advocate for changes in laws and policies related to harassment and gender discrimination in the workplace. Thus, celebrities' individual, isolated gestures (such as Beyoncé's) have been replaced by an alliance of women fighting issues long present in the feminist movement. In this context, Oprah's Golden Globes much talked-about speech become a high point of this collective effervescence in which she goes beyond a motivational speech. Indeed, she succeeded in translating individual experiences to a broader fight for recognition and justice (women's, African-Americans', and working class). She also positioned herself, not just as bearing witness to the suffering of others, but as a first-hand witness to her own experiences of discrimination, injustice and sexual abuse. Lastly, she depicted third-party vulnerable subjects of violence under the light of their courage, resistance, and achievements (even at the cost of their own lives); and her own popularity (and financial success) testifies to her resilience, determination and prosperity. Despite the problems that the association of resistance with professional success that celebrities embody (and proclaim) entitles in the formation of a new framework of recognition of the subject of violence, this new chain of unwavering events places such new conceptualization of gender violence at a critical point.

In the following pages, we first introduce the foregrounds of the ethical witnessing paradigm to set the key elements that ensure it as a useful mode to renovate gender violence narratives. After that, we delve into the analysis of Oprah's speech through the lens of the ethical witnessing paradigm, first, by examining the intersectional approach and the connections that the speech makes between gender violence and broader social fights; second, by inquiring the way in which victimhood, injurability and agency is tackled; and third, by investigating the relationship between giving testimony and bearing witness.

\section{Ethical witnessing for transformation}

Numerous feminist researchers contend that to succeed in the eradication of gender violence it is necessary to begin by challenging and subverting the existing frameworks of recognition of gender violence. First, these dominant frameworks define female identity through its intrinsic vulnerability or "injurability" (susceptibility to be wounded), in the words of Judith Butler and Athena Athanasiou (2013). In consequence, narratives about gender violence consistently deny women's agency (Butler, 2011), that is, their

4 The initiative information is available in https://www.timesupnow.com/ 
measures to escape violence (or ease its impact), to survive traumatic experiences, and to subvert the structures that promote the inequalities and oppressions that place them in such a vulnerable position. In this landscape, witnesses of women's victimization are placed in the role of (all-superior, all-benevolent) protectors, reinforcing that initial situation of subordination. This can also be said of people of color, lower socio-economic classes, those with disabilities, and other groups such as migrants and refugees who are also dispossessed (Butler and Athanasiou, 2013), defined by their injurability, and portrayed in the media as in need of a form of (patronizing) care and support -instead of participation and equality (Miller, 2004; Butler and Athanasiou, 2013).

The sight of the effects of violence, particularly of desecrated bodies, can be effective in denouncing the particular situations that led to it. However, it can achieve little more than to spark a sense of indignation in well-intended minds that do not experience such violence (Sontag, 2003; Kaplan and Wang 2004; Kaplan, 2005). Additionally, the recount of individual suffering singularizes the acts of violence, and presents them as unusual and isolated events (Radford, 2006; Messuti, 2015). In sum, the hegemonic modes of recognition of gender violence fail to recognize and address the basis of violence, such as the social inequalities and frustrations (Kimmel, 2013), and the intersections and configurations of patriarchy with other axes of oppression and inequality (Sokoloff \& Dupont, 2005; Jiwani, 2006), which conform various contexts of violence where the very significance of violence is embodied and rooted in cultural and social environments. The hegemonic interpretation of gender violence presents gender as a leveling axis (violence happens to women simply for being women), turning a blind eye to other impoverishing processes through racial/ ethnic group membership or sexual orientation that aggravate the difficulties of those in the margins who suffer violence (Sokoloff \& Dupont, 2005). Thinking that violence is the same for all women is to ignore that it affects women differently and, hence, the normative framework fails, after all, to articulate a political response that tackles the foundations of gender violence, namely, the inequality and oppression of certain ('injurable') subjects.

In the search for a paradigm shift in the representation of gender violence that would give rise to an ethical, but also a political response that could, ultimately, impact the eradication of the inequalities that cause the systemic violence, we turn to the theoretical concept of "ethical witnessing" (Oliver, 2001; 2004; Kaplan \& Wang, 2004; Kaplan, 2005; Wessels, 2010). The challenge lies in the recognition of the subject-victim as Other -and of the source, results and characteristics of their suffering- in its ethical dimension. That is, the need to go beyond a recognition formed by a frame of thinking that only recognizes what is familiar to us. In this limited recognition we judge based on certain social parameters. In fact, the value judgment acts as a fast track to formulate an ontological difference between the subject and the (pitied) object. Going beyond recognition means questioning the epistemic position from which we articulate recognition. For Kelly Oliver (2001), the dichotomy between subject and Other and between subject and object is, in itself, a pathology of oppression, since it enables the dehumanization inherent in oppression and domination. Going beyond recognition implies, therefore, recognizing the subjectivity of victims without subsuming it to what is familiar to the subject (by virtue of their experiences informed by race, class, gender, sexuality, disability, age, etc.), which actually conforms to their idea of the 'good victim' (as we saw, for example, in the case of la manada in Spain in which the victim of a gang rape was mistrusted 
because she had recovered and go on with her ordinary life after the rape, including hanging out with friends and updating her social media accounts) ${ }^{5}$.

This shift has two important implications in relation to responsibility. First, we are accountable for the way we denounce gender violence and the way we participate in the production of the testimony of victims. Second, we become responsible for articulating a political response after the reception. This ethical commitment to respond to the precariousness of the Other is linked to the articulation of responses that revert the structural conditions that create vulnerability -for it is not equally distributed (Butler 2006; Butler and Athanasiou, 2013).

Starting from this theoretical construct known as ethical witnessing, we were interested in assessing the capacity of Oprah Winfrey's speech to destabilize the modes of recognition of gender violence in the contexts of the \#MeToo and Time's $U p$ movements. In order to do so, we took into account the axes of analysis coming from the operationalization of the theoretical concept 'ethical witnessing' (Gámez Fuentes and Gómez Nicolau, 2017), that is, the connections that are established with the fights for women's rights and other fights for recognition, redistribution and participation (intersectionality and broader social and political demands); the degree of transgression of the reified models of identification of the subject-victim and the focus on the capacity of agency; and the type of relationship that develops between the subject who gives testimony and the witness.

\section{Intersectionality, representation, and the interweaving of violence with oppression}

Oprah began her speech with an autobiographical snapshot in which she referenced her modest upbringing and race, using descriptors that highlight the lack of resources -linoleum floor- and remark her racialization - contrasting actor Sidney Poitier's white tie with his black skin. With her initial remarks about Poitier receiving the Oscar in 1964, she said "I tried many, many times to explain what a moment like that means to a little girl, a kid watching from the cheap seats as my mom came through the door bone tired from cleaning other people's houses." In doing so she stressed the intersectional nature of inequality, namely being black and being poor. Then she moved onto adding another axis of discrimination: being a woman. While Poitier received the Cecil B. DeMille Award for a lifetime achievement at the Golden Globes in 1982, we had to wait thirty-six more years to see "the first black woman to be given this same award."

The denunciation of relations of exploitation and domination reached its zenith when Oprah alluded not just to the structural violence, but to the direct violence -aggressions that may be physical, psychological, sexual and economic- women are subjected to. She brought to our attention Recy Taylor, a black woman who was raped by six white men and left blindfolded in 1944 in Alabama. The men were never prosecuted for their crime. Thus, Oprah highlighted the connections between racial discrimination and violence against women and the power relations in terms of social class. In this sense, her concise speech made an effort to address the contexts and situations where violence and inequalities are generated.

For news articles in English, see https://www.theguardian.com/world/2017/nov/29/verdict-due-in-trial-of-fivemen-accused-of-gang-rape-in-spain; https://elpais.com/elpais/2017/11/30/inenglish/1512034885_930905.html 
Lastly, she referred in passing to \#MeToo and to the Time's Up campaign. Interestingly, the phrase "Me Too" was coined by African-American activist Tarana Burke in 2006 as a way to assure women of color suffering from sexually induced trauma that they were not alone, to suggest "empowerment through empathy" (Guerra,

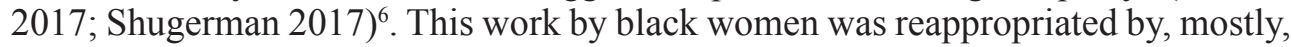
white women working in the entertainment industry or whose careers ended for not complying with sexual requests of men in power (for instance, producer Harvey Weinstein ${ }^{7}$ ). The structural and the direct violence suffered by women are not new, but celebrities' ability to reach vast audiences sparked a domino effect of global consequences of public knowledge and outrage. For instance, the Alianza Nacional de Campesinas (Latina Farmworkers National Alliance, US) pointed out in their letter of solidarity how

[W] wish that we could say we're shocked to learn that this is such a pervasive problem in your industry. Sadly, we're not surprised because it's a reality we know far too well. Countless farmworker women across our country suffer in silence because of the widespread sexual harassment and assault that they face at work (Time Staff, 2017).

Following Alianza's letter of solidarity, Time's Up initiative (made up of more than 300 women in the entertainment industry) acknowledged their privileged situation and "the fact that we have access to enormous platforms to amplify our voices [...] which have drawn and driven widespread attention to the existence of this problem [...] that farmworker women and countless individuals employed in other industries have not been afforded" (Time's Up, 2018). They then go on to mention farmworkers, housekeepers, janitors, waitresses, factory workers, domestic workers, home health aides, and immigrant women. In their foundational letter 'Dear Sisters', they acknowledge how "the lack of financial stability makes [women working in low-wage industries] vulnerable to highrates of gender-based violence and exploitation," and how "this systemic gender-inequality and imbalance of power fosters an environment that is ripe for abuse and harassment against women" (Time's Up, 2018), signaling the intersectional nature of violence. In the same vein, Time's $U p$ tries to be inclusive of women of color, immigrant, disabled, lesbian, bisexual and transgender women, "whose experiences in the workforce are often significantly worse than their white, cisgender, straight peers." (Time's Up, 2018).

Nevertheless, despite attempts of being inclusive, the movement led by celebrities falls short of incorporating women outside the workforce or engaged in non-traditional and illegal work such as sexual workers. Additionally, celebrities reproduce a paternalistic form of protection by assigning themselves the task of lifting up "the voices, power and strength" of those women (Time's Up, 2018).

6 Brené Brown (2012) also suggests that empathy is an antidote to shame because it grows exponentially when there is secrecy, silence and judgment, and that "the two most powerful words when we are in struggle [are]: Me too." Further information in

https://web.archive.org/web/20171016112800/https://www.washingtonpost.com/news/morning-mix/ wp/2017/10/16/me-too-alyssa-milano-urged-assault-victims-to-tweet-in-solidarity-the-response-was-massive/ 


\section{Vulnerability, agency, resistance and the subject-victim}

As we discuss above, "being ascribed the status of victim is [...] an act of marginalization" (Coates and Ridley, 2009, p. 110) that reflects "male supremacist thinking" -women as the "weaker sex" (hooks, 1984, p. 45)-, and that ultimately hinders social transformation. However we cannot eliminate discourses of victimhood altogether as long as the violences continue. What we can do is change the way that violence is understood and represented. Despite Oprah's denunciation of the vulnerable position of women -whether of color, working-class and even privileged and white- she presented them as strong, capable, and inspiring agents. Furthermore, she emphasizes their discursive abilities. She transforms stories of 'injurability' into practices of resistance, of solitary resistance into collective resistance and, therefore, into a social and political fight. After all, "the power to tell a story [...] under the conditions of one's own choosing, is part of the political process" (Plummer, 1995, p. 26). Oprah mentions how Recy Taylor, despite the death threats she received, reported the sexual assault to the National Association for the Advancement of Colored People (NAACP). Oprah also spoke of Rosa Parks, considered an icon of resistance to racial segregation and mother of the freedom movement. Parks is well known for being active in the Civil Rights Movement in the US, and symbolically, for refusing to stand up to allow a white man to sit down in a bus' 'colored' section in Alabama at a time of racial segregation'. In fact, Parks was the person sent by the NAACP to investigate the crimes against Recy Taylor. Oprah goes from mentioning a particular subject-victim to a subject-victim activist, to all-subject-victim women regardless of race, class, sexuality, etc., focusing on their resistance, bravery and capacity for action: "[Recy Taylor] lived as we all have lived, too many years in a culture broken by brutally powerful men. For too long, women have not been heard or believed if they dare speak the truth to the power of those men." And she continues:

It's one [story] that transcends any culture, geography, race, religion, politics, or workplace. So I want tonight to express gratitude to all the women who have endured years of abuse and assault because they, like my mother, had children to feed and bills to pay and dreams to pursue. They're the women whose names we'll never know. They are domestic workers and farm workers. They are working in factories and they work in restaurants and they're in academia, engineering, medicine, and science. They're part of the world of tech and politics and business. They're our athletes in the Olympics and they're our soldiers in the military (Winfrey, 2018).

Oprah set in motion an agency-building process that allowed us to go from the identification of the singularity of the victim to the correlation of the injustices to which victims are collectively subjected. In the process, she enables the articulation of collective responses and the restitution of agency through interdependence with

\footnotetext{
8 White people had priority seating even in the section reserved for black people on the rear of the bus. Parks' gesture of defiance took place in 1955 in Montgomery, and it cost her being arrested and charged with a violation of the segregation laws.
} 
others. Oprah highlights women's capacity for fighting back: "I'm especially proud and inspired by all the women who have felt strong enough and empowered enough to speak up and share their personal stories". Because for her, women's first experience of subjectivity-building begins with having a voice and telling a story; a story that includes "shame, how we love and how we rage, how we fail, how we retreat, persevere and how we overcome." She pays particular attention to victims' capacity for resilience: "I've interviewed and portrayed people who've withstood some of the ugliest things life can throw at you, but the one quality all of them seem to share is an ability to maintain hope for a brighter morning, even during our darkest nights" (Winfrey, 2018).

Although Oprah focused on (and promoted) the articulation of subjectivity and resistances, she also constructed victims as superheroines carrying a halo, as "magnificent women" with "an ability to maintain hope for a brighter morning". She constructed an epitome of the 'good victim', leaving no room for those who do not adhere to this image. Her focus on victims as resilient ultimately supports a neoliberal thought that reduces successful victims to those who are able to overcome adversity, dismissing the individuals living under harsh structural conditions who are just trying to survive with a certain dignity (Bracke, 2016). In addition, she ultimately seemed to allude to having leaders as 'the way' to make changes in society, promoting changes top down instead of as a grassroots or combined effort - "fighting hard to make sure that they become the leaders who take us to the time when nobody ever has to say 'Me too' again" (Winfrey, 2018). In this sense, she is indicating the necessity to end with the male-dominated, "impenetrable monopoly" that "fosters an environment that is ripe for abuse", and to build centers of power ("from legislatures to boardrooms to executive suites and management to academia") that posses "gender parity" and "equal decision-making authority" (Time's Up, 2018). It is hard to forget that her speech and personal trajectory associate the power to overcome injurious experiences to success and the conquest of places of power in the social mesh. In sum, her (and other celebrities') experiences transgress the interpretation of the subject-victim of gender violence as devoid of agency, as hopelessly vulnerable; however, they can hardly function as synecdoche of women experiences outside the exemplar victim model, and/or the celebrity world.

\section{Testimony and bearing witness}

According to Dori Laub (cited in Kaplan, 2005), in the process of ethical witnessing there are three levels: the testimony that gives account of a first-hand experience of violence, the person who gives an account of the testimony of other people as witness, and the joint search for an elusive truth (inasmuch as traumatic memories escape logic memory and recount) between the person that gives testimony and the person/s who bears witness to the event itself. We can categorize this dynamic as one that fosters (a) some empathy and identification with the subject that testifies, (b) a more committed listener who exercises an ethical responsibility when it comes to allowing a painful or embarrassing discourse emerge, and (c) a joint search for a reality that reveals a structural social problem and a shared responsibility and commitment to face it. 
Oprah bears witness to the pain of gendered and racialized bodies: Recy Tylor's, Rosa Parks', and all those women -"whose names we'll never know". Oprah, however, has always been very vocal about her own traumatic experiences:

I'm Oprah Winfrey and like millions of Americans, I'm a survivor of child abuse. I was only 9 years old when I was raped by my 19 -year-old cousin. $\mathrm{He}$ was the first of three family members to molest me. I kept the abuse a secret over twenty years. Every year in America nearly three million cases of child abuse are reported. Who knows how many go unreported? We are here tonight to face this national epidemic of child abuse and neglect (from the Oprah Winfrey Show; cit. Plummer 1995, p. 95).

In that sense, her speech combines the double dimension of giving testimony and bearing witness to oppressive experiences, despite her acknowledgement that her social position is, nowadays, one of privilege. She remarks the importance of speaking out, giving testimony, of "uncovering the absolute truth that keeps us from turning a blind eye to corruption and to injustice. To tyrants and victims, and secrets and lies [...] [S]peaking your truth is the most powerful tool we all have" (Winfrey, 2018). Her whole professional trajectory has been built upon her new approach to media; she is one of the most popular contributors to confessional television, which focuses on giving voice to stories that focus on 'breaking the silence', on 'coming out', and on 'surviving' (Plummer, 1995, pp. 101, 95).

The recognition of the structural, cultural and also physical and direct forms of violence (Galtung, 1990) is facilitated by the references to multiple situations that connect different cultural contexts -from the 50s, 60s and 70s to 2017-, placing Oprah's speech in the ethical dimension since it aims to reveal the pillars that sustain this violence: the protection of the institutions that distrust the stories of women and children, legitimated by a phallocratic culture. At the same time, she calls to action; her ultimate goal is to advocate for change, for the disruption of the chauvinist status quo: "the truth of so many [...] women who were tormented in those years, and even now tormented, goes marching on" (Winfrey, 2018).

She does so by inviting us to be part of an optimistic vision of the future, to contribute to its making:

So I want all the girls watching here, now, to know that a new day is on the horizon! And when that new day finally dawns, it will be because of a lot of magnificent women, many of whom are right here in this room tonight, and some pretty phenomenal men, fighting hard to make sure that they become the leaders who take us to the time when nobody ever has to say 'Me too' again (Winfrey, 2018).

In the act of bearing witness, she plays a key role as she has the instruments and power to capture testimonies, to endorse witnesses, and to prompt transformation. In fact, her way to influencing people has been termed 'the Oprah effect' (including her ability selling books, attaining millionaire donations to support different causes, supporting wining campaigns such as Barack Obama's presidential campaign, etc.). The stories she tells, and how she tells them, prompt a sense of transformation and 
empowerment. All things considered, she "succeeds in creating shared spaces and experiences and in shaping attitudes" (Gámez Fuentes and Maseda, 2018, p. 7), and she promotes some ways in which people can work towards social transformation: through speaking up/a commitment to respond, and partaking in the \#MeToo and Time's Up Legal Defense Fund (due to the expansive influence of these movements $)^{9}$. Her interviewing style, which made her famous and broadly likeable, departed from the professional distance of others to the sharing of confessions about weight problems, love life and sexual abuse with her interviewees, to the point that she has created a new media style called "rapport talk" (instead of "report talk"). Plummer (1995) argues that Oprah's appeal lies in the witnesses' feelings of not being judged, although her 'confessional style' enacts, after all, a power relation where the person who confesses is at the 'mercy' of the interlocutor who mediates, comforts, advices, and appeases (Foucault, 1978; Wilson, 2003; King, 2008). In this regard, her approach cannot be considered as conducive to a form of ethical witnessing. Furthermore, her interventions are framed as part of the entertainment industry and her success ultimately points to the commercialization of suffering, thus to a form of voyeurism.

Lastly, despite her capacity to set, not only discourses of truth regarding intimate citizenship issues (Plummer, 2003), but to also have the resources to realize projects that deal with equal opportunities and women's rights ${ }^{10}$, it is hard to discern the steps from enunciating violence to facilitating the resolution of violence and its damage at the structural level. That is, actions of denunciation do not entail changes in social problems if they are not accompanied by social policies that aim to transform the conditions of vulnerability and changes in consciousness.

Celebrities remain powerful spokespersons for their ability to reach vast audiences, their capacity to influence opinions and actions. The momentum achieved by speaking out, through the \#MeToo and Time's Up initiatives praised and supported by Oprah in her speech, seems to point to the widespread commitment to fight sexual harassment and gender violence. It remains to be seen the consequences: will it create a backlash movement (Faludi, 1991; Cohn, 2018) (as suggested by the open letter signed by one hundred prominent French women, and published in Le Monde ${ }^{I l}$ )? Will it wane and become a yet another form of commercialization of the feminist struggle?

\section{Women march on: Conclusions}

On January 72018 at the Golden Globes ceremony, Oprah capitalized on her status as one of the most influential person on the planet to send a message about equality. Hers was a deliberate speech that tackled the connections between gender violence and other types of violence and axes of inequality. She connected human

9 One of the core Time's Up's mission is to “improve laws, employment agreements, and corporate policies; help change the face of corporate boardrooms and the C-suite; and enable more women and men to access our legal system to hold wrongdoers accountable" by creating a Legal Defense Fund (Time's Up, 2018).

10 Such as the Peace Over Violence (formerly the Los Angeles Commission on Assaults Against Women), V-Day, Women for Women International, The Women in the World Foundation, and the Oprah Winfrey Leadership Academy for Girls in South Africa.

11 The full letter is provided in English in the following link https://www.worldcrunch.com/opinion-analysis/fulltranslation-of-french-anti-metoo-manifesto-signed-by-catherine-deneuve 
rights, women's rights and feminist fights and, following the model of social movements activism, she invited the construction of alliances (like Emma Watson did in her \#HeForShe campaign). In addition, the destabilizing potential of her speech is located in the exploration of the resistances, the trust in the agency and activism (political engagement) she encouraged. Oprah highlighted the courage found in injured women, verging on heroism. Lastly, she acted as someone who both witnessed her own victimization, and who bears witness by facilitating the testimonies of those to dare to speak out, publicly denouncing the structural violence and creating venues for change (and encouraging others to follow suit). In our opinion, the activity of public figures, like Oprah and all celebrities involved in the \#MeToo movement and the Time's Up initiative, has the potential to transgress the boundaries of the current mode of recognition and representation of gender violence.

Nevertheless, the accepted image of Oprah as a guru assumes a hierarchical relation that contravenes an ethical dimension of witnessing. Furthermore, we are unaware if people making confessions transform their stories of suffering into action to transform the social circumstances that favored such suffering, and how. In addition, in line with a liberal position, Oprah focuses on the idea of individual empowerment as the way to overcome vulnerability, and she places the feasibility of eradicating gender inequality ultimately on the conquest of power. This vision might actually impede social transformation: if victims do not break but "bounce back" (Bracke, 2016, p. 69) the necessity of change diminishes. We also hope for a brighter future, but one that, beyond the neoliberal discourse of female empowerment (or its opposite, victimization), proposes the idea of the power of (female) bodies (and minds) that act together -the "bodies in alliance" (to use Judith Butler's nomenclature)- fighting gender violence.

\section{References}

Bracke, S. (2016). Bouncing Back. Vulnerability and Resistance in Times of Resilience. In J. Butler, Z. Gambetti \& L. Sabsay (eds.), Vulnerability in Resistance (pp. 52-75). Durham \& London: Duke University Press [eBook].

Brown, B. (2012). Listening to shame. TEDtalk2012. Retrieved from https://www.ted.com/ talks/brene_brown_listening to shame\#t-1132803 (Accessed 13-01-2018).

Butler, J. (2006). Precarious Life: the Powers of Mourning and Violence. London: Verso.

Butler, J. (2011). Bodies in Alliance and the Politics of the Street. Keynote delivered in Venice (Italy) in The State of Things, organized by the Norwegian Office for Contemporary Art. Retrieved from http://eipcp.net/transversal/1011/butler/en

Butler, J. \& Athanasiou, A. (2013). Dispossession: the Performative in the Political. Cambridge, UK: Polity Press.

Chan, S. (2017). Recy Taylor, Who Fought for Justice After a 1944 Rape, Dies at 97. The New York Times (Obituaries). Dec 29, 2017. Retrieved from https://www.nytimes. com/2017/12/29/obituaries/recy-taylor-alabama-rape-victim-dead.html

Coates, L. \& Ridley, P. (2009). Representing Victims of Sexualized Assault. In Faulkner, E. \& MacDonald, G. (eds.), Victim No More: Women's Resistance to Law, Culture, and Power (pp. 109-124). Halifax: Fernwood Publishing.

Cohn, J. (2018). \#Womenagainstfeminism. Towards a Phenomenology of Incoherence. In Keller, J. \& Ryan, M. E. (eds.), Emergent Feminisms. Complicating a Postfeminist Media Culture (pp. 176-192). New York \& London: Routledge. 
Faludi, S. (1991). Backlash. The Undeclared War Against American Women. New York: Crown. Foucault, M. (1978). The Will of Knowledge. The History of Sexuality, vol. 1. (Trans.) Robert Hurley. London: Penguin Books.

Galtung, J. (1990). Cultural Violence, Journal of Peace Research, 27(3), 291-305.

Gámez Fuentes, M. J. \& Maseda, R. (eds.) (2018). Gender and Violence in Spanish Culture: From Vulnerability to Accountability. New York: Peter Lang.

Gámez Fuentes, M. J.; Gómez Nicolau, E. (2017). El 'testimonio ético' como modelo analítico en la comunicación para el cambio social. Investigação Qualitativa em Ciências Sociais, 3, 170-179.

Gámez Fuentes, M. J.; Gómez Nicolau, E. \& Maseda, R. (2016). Celebrities, violencia de género y derechos de las mujeres: ¿Hacia una transformación del marco de reconocimiento? Revista Latina de Comunicación Social, 71, 833-852. DOI: 10.4185/RLCS-2016-1123.

Guerra, C. (2017). Where did 'MeToo' come from? Activist Tarana Burke, long before hashtags. Boston Globe. Oct 17, 2017. Retrieved from https:/www.bostonglobe.com/ lifestyle/2017/10/17/alyssa-milano-credits-activist-tarana-burke-with-founding-metoomovement-years-ago/o2Jv29v6ljObkKPTPB9KGP/story.html

hooks, b. (1984). From margin to center. Boston: South End.

Jiwani, Y. (2006). Discourses of Denial: Mediations of Race, Gender, and Violence. Vancouver: UBC Press.

Kaplan, A. (2005). Trauma Culture. The Politics of Terror and Loss in Media and Literature. New Brunswick, New Jersey \& London: Rutgers University Press.

Kaplan, A. \& Wang, B. (eds.) (2004). Trauma and Cinema. Cross-Cultural Explorations. Hong Kong: Hong Kong University Press.

Kimmel, M. (2013). Angry White Men: American Masculinity and the End of an Era. New York: Nation Books.

King, B. (2008). Stardom, celebrity and the para-confession. Social Semiotics, 18(2), 115132. DOI: $10.1080 / 10350330802002135$

Messuti, A. (2015). La dimensión jurídica internacional del feminicidio. In G. Atencio (ed.), Feminicidio. El asesinato de mujeres por ser mujeres (pp. 37-61). Madrid: Fibgar \& Catarata.

Miller, A. (2004). Sexuality, Violence Against Women, and Human Rights: Women Make Demands and Ladies Get Protection. Sexuality, Human Rights and Health, 7(2), 16-47. DOI: $10.2307 / 4065347$

Oliver, K. (2001). Witnessing: Beyond Recognition. Minneapolis: University of Minnesota Press. DOI: 10.1080/1353464032000171118

Oliver, K. (2004). Witnessing and Testimony. Parallax, 10(1), 79-88.

Plummer, K. (1995). Telling Sexual Stories. Power, Change and Social Worlds. London and New York: Routledge.

Plummer, K. (2003). Intimate Citizenship. Private Decisions and Public Dialogues. Seattle and London: University of Washington Press.

Radford, J. (2006). ¿De aquí por dónde seguimos. In J. Radford \& D. Rusell (eds.), Feminicidio. La política del asesinato de las mujeres (pp. 665-678). México: UNAM.

Sontag, S. (2003). Regarding the Pain of Others. New York: Farrar, Strauss and Giroux.

Sokoloff, N. \& Dupont, I. (2005). Domestic Violence at the Intersections of Race, Class, and Gender. Challenges and Contributions to Understanding Violence Against Marginalized Women in Diverse Communities. Violence Against Women, 11, 38-64.

Shugerman, E. (2017). MeToo: Why are women sharing stories of sexual assault and how did it start? Independent. Oct 17, 2017. Retrieved from https://www.independent.co.uk/ 
news/world/americas/me-too-facebook-hashtag-why-when-meaning-sexual-harassmentrape-stories-explained-a8005936.html

Time staff (2017). 700,000 Female Farmworkers Say They Stand With Hollywood Actors Against Sexual Assault. Times. Nov 10, 2017. Retrieved from http:/time.com/5018813/ farmworkers-solidarity-hollywood-sexual-assault/

Time'sUp (2018). Dear Sisters. Jan 1, 2018. Retrieved from https://www.timesupnow.com.

Wessels, E. (2010). The Politics of Ethical Witnessing: The Participatory Networks of 9/11 Media Culture. Thesis submitted to the University of Minnesota.

Wilson, S. (2003). Oprah, Celebrity and Formations of the Self. New York and Hampshire, UK: Palgrave Macmillan.

Winfrey, O. (2018). Oprah Winfrey Receives the Cecil B. deMille Award. Golden Globes 2018. Retrieved from https://www.youtube.com/watch?time_continue=3\&v=LyBims8OkSY 